\title{
Polgármesterek inkumbencia előnye a megyei jogú városokban Magyarországon
}

\author{
PETROVSZKI LÁSZLÓ1
}

\begin{abstract}
ABSZTRAKT
Huszonhárom megyei jogú város van Magyarországon. Ezek a városok az országban különösen fontos szerepet töltenek be, mind központi elhelyezkedésük, mind népességszámuk alapján, valamint kiemelt adminisztratív feladataik okán. Emiatt a választások idején értékes zsákmányai a politikai aktoroknak és pártoknak. Tanulmányomban ezeket a településeket vizsgálom az inkumbens polgármesterek szempontjából. Az inkumbencia, vagyis az inkumbenspolitikus azt jelöli, aki éppen politikai tisztséget tölt be. Kvantítatív összehasonlítással megvizsgálom, hogy az úgynevezett inkumbens előny megjelenik-e ezekben a városokban. Elemzem, hogy az első rendú választásokon (általános választások) győztes pártok jelöltjei jobban szerepelnek-e a polgármester-választáson.
\end{abstract}

KULCSSZAVAK: inkumbencia, önkormányzati választások, polgármesterek, választáspolitológia, másodrendû választás, megyei jogú városok

\section{ABSTRACT}

\section{Incumbency advantage of mayors in cities with county rights in Hungary}

There are twenty-three cities with county rights in Hungary. These cities are playing extremely important role because of their location, population and their administrative duties. For these reasons they can fall prey to national parties and political actors even during local elections. The aim of this study is to analyze these settlements in regard to the incumbency of mayors. Incumbency means the holding of an office, and the incumbent politician is the current holder of a political office. My goal is to show - by quantitative comparison - that the so-called incumbent advantage is prevalent in these cities. I also examine whether the candidates of the winning parties at the first order general elections are faring better than their competitors.

KEYWORDS: incumbency, local elections, mayors, electoral studies, second order elections, cities with county rights

\footnotetext{
${ }^{1}$ Doktorandusz, Szegedi Tudományegyetem, Politológiai Tanszék, petrovszki@polit.u-szeged.hu
} 


\section{Bevezetés}

Inkumbensnek nevezi a politikatudomány azt a politikust, aki éppen betölt valamilyen választás útján elnyerhető politikai tisztséget. A választáspolitológia számára különösen érdekes az inkumbencia vizsgálata: az ebben az állapotban lévő jelöltek a legtöbb kutatás szerint előnyt élveznek, azaz gyakran kerülnek újra megválasztásra (Kozma - Kumin 2011). Ezt a jelenséget hívja a szakma inkumbencia előnynek.

Az inkumbencia előny vizsgálatában élen járnak az Amerika Egyesült Államok kutatói (Erikson 1971, Levitt 1997). Többször kimutatásra került, hogy a Kongreszszus képviselői közül az inkumbens jelölteknek jelentős előnyük van, és legtöbbször újra megválasztásra kerülnek.

Az inkumbencia előny többségi rendszerekben tud kialakulni, ahol a személynek szóló szavazat (personal vote) (Papp 2016) erőteljesebben befolyásolja az állampolgárokat. Az arányos rendszerekben, ahol nem feltétlenül a területi képviseleti elv a döntő, a választópolgárok inkább pártszimpátia szerint döntenek. Az inkumbencia előny gyakorlatiasabb magyarázata, hogy a hivatalban lévő politikus könnyebben hozzáférhet a választáson előnyt biztosító eszközökhöz és forráshoz, ezzel vetélytársaihoz képest előnyhöz jutva. Papp Zsófia tanulmánya viszont rámutat arra, hogy az inkumbens jelöltek hátrányt is szenvedhetnek, tanulmányának esetében például az országgyűlési egyéni választókerületekben indulók (Papp 2016). Ezt a jelenséget az inkumbens-hátrány fogalma írja le.

Az inkumbencia előny Magyarországon kevéssé kutatott terület. Ezen a területen úttörő jelentőségű Kozma Viktória és Kumin Ferenc tanulmánya a magyar polgármesterek inkumbenciájáról. Kijelölik a jelenség kutathatóságának potenciális útvonalait, melyek a magyar választási rendszerből, illetve rendszerekből fakadnak (Kozma - Kumin 2011). Az országgyűlési képviselők esetében bár mind a 2014 előtt, mind a 2014-től a képviselők körülbelül felét egyéni kerületi rendszerben választják, ezekben a kerületekben mégis sokkal inkább a pártok aktuális sikerei befolyásolják az eredményeket és nem a jelölt személyes karizmája. További fontos tényező, hogy 2010-ig kétfordulós volt a választás az egyéni kerületekben, így a kihívónak és az mögé beálló ellenzéki pártoknak lehetősége volt az inkumbens jelölt feletti győzelem a második fordulóban.

Ezzel szemben a polgármesterek választása 1994 óta minden magyarországi településen közvetlen, egyfordulós first-past-the-post rendszerben zajlik. A polgármesterek vizsgálata ezért a legkézenfekvőbb a magyarországi politikai versenyteret és rendszert tekintetbe véve.

\section{Hipotézis és módszertan}

Elfogadva Kozma és Kumin kvantitatív vizsgálatát a 2002-2010 közötti időszakra, kijelenthető, hogy a magyar polgármester-választásokon magas arányban szerepet 


\section{TEMATIKUS TANULMÁNYOK - Önkormányzati választások elméletben és gyakorlatban}

játszik az inkumbencia előny (Kozma - Kumin 2011). További fontos megállapításuk, hogy a lakosságszám csökkenésével fordítottan arányos az inkumbens polgármesterek újraválasztási mutatója.

Jelen tanulmányomban Magyarország legfontosabb városait, a megyei jogú városokat vizsgálom a polgármester-választásokon megjelenő inkumbencia előny szempontjából. A döntésem önkényesnek tűnhet, de a politikai szereplők és a közélet számára is kiemelt jelentőséggel bírnak ezek a települések, ahogy a 2019. évi önkormányzati választások utáni ellenzéki értékelések is mutatják. Az egyik kiemelt sikerkommunikációjuk, hogy huszonháromból tíz városban az ellenzéki összefogás jelöltje győzött.

További indok a megyei jogú városok vizsgálata mellett, hogy a huszonhárom település közül húsz Budapest után a legnagyobb lakosságszámmal rendelkezik, míg a maradék három közül kettő megyeszékhely (Salgótarján és Szekszárd). A megyei jogú városok jogállását a 2011. évi CLXXXIX. törvény (Mötv.) szabályozza. Ez alapján megyei jogú városok a megyeszékhelyek és a törvény hatálybalépéséig megyei jogú várossá nyilvánított települések, így a számuk valószínűleg nem fog bővülni a közeljövőben. Lényeges gyakorlati különbség más településekhez képest, hogy bizonyos feladatköröket az adott megyei közgyúléssel közösen kell ellátniuk, valamint a megyei jogú városok lakosai nem szavazhatnak a megyei közgyűlés megválasztásánál a jelölőszervezetek listáira.

A Nemzeti Választási Iroda nyilvánosan elérhető adatbázisa csak 1994-től biztosít megfelelő adatokat az önkormányzati választásokra, így ez a vizsgálatom kiinduló dátuma. A saját számításaimhoz a www.valasztas.hu oldalon található választási eredmények adatait használom. Az utolsó vizsgált választás a 2019-es. Érd csak 2006 óta rendelkezik megyei jogú városi ranggal, de jelen tanulmányban a 2006 előtti érdi eredményeket is figyelembe veszem.

Csak a teljes ciklus utáni választásokat veszem figyelembe, az időközi választásokkal nem foglalkozom. Inkumbencia vizsgálat szempontjából e választások elhanyagolhatóak, mivel akkor következnek be, ha a hivatalban lévő polgármester pozícióját valamilyen rendkívüli oknál fogva nem tudja betölteni, így az újraindulása nem valószínü.

Nem vizsgálom Budapestet, mely speciális jogállással bír Magyarországon, illetve teljes körű áttekintése külön tanulmányt érdemelne.

Hipotézisem, hogy az inkumbencia előny ezekben a városokban is meghatározó elem. További feltevésem, hogy az aktuális kormánytöbbséget bíró pártoknak több polgármester-jelöltje tudja megtartani vagy megszerezni a tisztséget, mint a nem kormánypárti jelöltek. Az ellenzéki kifejezését azért nem használom tanulmányomban ezekre a jelöltekre és polgármesterekre, mert sok esetben ennek megállapítása nem egyértelmú. Független vagy nem pártszervezet támogatásával is indulhattak, ezért politikai hovatartozásuk részletes megállapítása nem lehetséges. 
TEMATIKUS TANULMÁNYOK - Önkormányzati választások elméletben és gyakorlatban

Egyszerű kvantitatív módszereket használva elemzem, hogy mi az újraválasztási ráta a megyei jogú városokban választásról választásra és anomáliákat, összefüggéseket keresek a megyei jogú városok polgármester-választásain.

\section{Újraválasztások száma}

Az újraválasztások számának megállapításánál azt vettem figyelembe, hogy az előző polgármesteri-választásokon győztes jelölt a következő választások alkalmával is sikeresen megszerezte-e a pozíciót. Ennek vizsgálatával megállapítható, hogy milyen mértékben van jelen az inkumbencia előny ezekben a városokban. Tovább segít megkülönböztetni az extrém eseteket.

1. táblázat. Újraválasztások számának megoszlása a megyei jogú városokban

\begin{tabular}{|c|c|}
\hline Újraválasztások száma & Újraválasztások megoszlása \\
\hline 6 újraválasztás & 1 \\
\hline 5 újraválasztás & 2 \\
\hline 4 újraválasztás & 8 \\
\hline 3 újraválasztás & 8 \\
\hline 2 újraválasztás & 3 \\
\hline 1 újraválasztás & 0 \\
\hline 0 újraválasztás & 1 \\
\hline
\end{tabular}

Forrás: saját szerkesztés

1994 és 2019 között hét önkormányzati választás került megrendezésre. A táblázatból kivehető, hogy a legtöbb városban a választások körülbelül felénél, azaz három vagy négy alkalommal újrázni tud a polgármester. 
TEMATIKUS TANULMÁNYOK - Önkormányzati választások elméletben és gyakorlatban

2. táblázat. Újraválasztások száma településenként

\begin{tabular}{|l|c|}
\hline \multicolumn{1}{|c|}{ Település } & Újraválasztások száma \\
\hline Szekszárd & $\mathbf{4}$ \\
\hline Salgótarján & 3 \\
\hline Hódmezővásárhely & 3 \\
\hline Dunaújváros & $\mathbf{2}$ \\
\hline Nagykanizsa & $\mathbf{0}$ \\
\hline Eger & 3 \\
\hline Zalaegerszeg & $\mathbf{4}$ \\
\hline Békéscsaba & $\mathbf{4}$ \\
\hline Veszprém & $\mathbf{4}$ \\
\hline Sopron & 3 \\
\hline Kaposvár & $\mathbf{6}$ \\
\hline Érd & 3 \\
\hline Tatabánya & $\mathbf{4}$ \\
\hline Szolnok & 3 \\
\hline Szombathely & $\mathbf{2}$ \\
\hline Székesfehérvár & $\mathbf{4}$ \\
\hline Kecskemét & 3 \\
\hline Nyíregyháza & $\mathbf{5}$ \\
\hline Győr & $\mathbf{5}$ \\
\hline Pécs & $\mathbf{2}$ \\
\hline Miskolc & 3 \\
\hline Szeged & 4 \\
\hline Debrecen & 4 \\
\hline
\end{tabular}

Forrás: saját szerkesztés

Városi bontásban kitűnnek azok, ahol feltűnően magas vagy alacsony az újraválasztások száma. Alacsonynak a kettő vagy annál kevesebbet, míg magasnak a négy vagy annál több újraválasztást tekintem. A fenti kategóriákba eső városokat egyesével vizsgálom.

Nagykanizsán egyszer sem tudott győzedelmeskedni az inkumbens polgármester. Ennek legfőbb oka, hogy mindössze kétszer indult el tisztséget betöltő polgármester újra a választásokon, így ennél többször esély sem volt újrázni. Az első kísérlet a pozíció megtartására 1998-ban volt. Suhai Sándor, aki 1994-ben még az MSZP színeiben szerzett pozíciót, 1998-ban már függetlenként indult. A Magyar Szocialista Párt Tüttő Istvánt támogatta. Suhai mindössze a szavazatok 5,57\%-át szerezte meg, pedig 1994-ben a szavazatok 43,98\%-a jutott neki. A kézenfekvő magyarázat 
bukására a párttámogatás elvesztése, melyet alátámaszt, hogy az MSZP jelöltje szerezte meg a tisztséget.

A következő eset, amikor indult Nagykanizsán inkumbens jelölt 2006-ban volt. 2002-ben Litter Nándor győzedelmeskedett az MSZP-vel, de 2006-ra az előző esethez hasonlóan függetlenként indult. Hatalmas szavazatvesztés érte őt is: 2002-ben 60,29\% jutott neki, 2006-ban már csak 33,4\%. Mindeközben 2006-ban az MSZP jelöltje, Gáspár András 22,15\%-ot kapott! A párttámogatás hiánya az első esetben 38,41\%-os veszteséget, míg a másodiknál 26,89\%-os hiányt okozott.

Dunaújvárosban négyszer próbálkozott újra az aktuális polgármester a pozíciója megtartásával, de csak kettő alkalommal volt sikeres. Almási Zsolt 1994-ben a Szabad Demokraták Szövetségének színeiben szerzett mandátumot, a szavazatok 40,62\%-kal, de 1998-ra már csak a szavazatok 18,38\%-át tudhatta magáénak és nem tudta megtartani tisztségét. A 2002-ben polgármesterré választott MSZP-s Kovács Pál 2006-ban újraválasztásra került, de 2010-ben már nem indult. 2010-ben a Fidesz támogatású Cserna Gábor került pozícióba, aki 2014-ben is megtartotta azt. 2019-ben azonban a Rajta Újváros! Egyesület támogatásával induló Pintér Tamás legyőzte. Cserna Gábor három eredménye időrendben a következő: 2010-ben 47,14\%, 2014-ben 45,34\% és 2019-ben 41,04\%. Az inkumbencia előny ebben az esetben nem biztosított többletszavazatot, csak a stagnáláshoz volt elegendő, ezért 2019-ben nem tudta már megtartani a pozícióját Cserna Gábor.

Szombathelyen a hét választásból ötször indult újra a polgármester, mégis csak kétszer tudott újra győzni. Szombathely erősen követi az országos politikai változásokat, hiszen minden kormányváltási évben új polgármestert választott magának (1998, 2002, 2010). 2019-ben visszavonult az inkumbens Puskás Tivadar, így új kihívó tudott pozíciót szerezni.

Pécsett kétszer indult újra pozícióban lévő polgármester, s mind a kétszer győzedelmeskedni is tudott. A város polgármester-választásainak egyediségét adja, hogy 1994-1998 közötti városvezető, 1998-ban és 2002-ben nem indult újra, de 2006-tól már ismét megmérettette magát. Ennek ellenére csak 2010-ben szerezte vissza a polgármesteri címet és 2014-ben meg is védte azt. Az inkumbencia előny kvantitatív vizsgálatánál az ilyen visszatérést nem lehet figyelembe venni, mindazonáltal valószínűsíthető, hogy helyi ismertsége hozzásegítette az újbóli győzelemhez.

A spektrum másik oldaláról, a magas újraválasztási rátával rendelkező tizenegy várost emelem ki. Szekszárdon három polgármester töltött be tisztséget. Kocsis Imre az SZDSZ színeiben 1994 és 2002 között vezette a várost, de a 2006-os választásokon nem tudott győzelmet elérni. Horváth István a Fidesz-KDNP színeiben vette át a vezetést, de 2014-ben nem indult újra, ezért a szintén Fidesz-KDNP támogatásával rajthoz álló Ács Rezső győzedelmeskedett. A hat választásból tehát ötször indult inkumbens jelölt, ebből négyszer győzni is tudott. 
Zalaegerszeget 1994 óta a Fidesz és az azzal éppen szövetséges jobboldali pártok jelöltjei vezetik. 2010-ig Gyimesi Endre irányította a várost, 2010-ben nem indult újra és utódja, Gyutai Csaba 2014-ben nem indult. 2014-től Balaicz Zoltán a polgármester. Négy esetben indult újra inkumbens jelölt és mind a négyszer pozíciót is szerzett.

Békéscsabán 2006-ig az SZDSZ-es Pap János volt a polgármester. 2006-ban elveszítette a választásokat a Fidesz-KDNP jelöltjével, Vantara Gyulával szemben. 2014ben Vanatara Gyula nem indult újra és a független színekben politizáló Szarvas Péter vette át a vezetést. Ötször indult újra inkumbens pozícióból a polgármester és négyszer győzedelmeskedni tudott.

Veszprém Békéscsabához szinte teljesen megegyező utat járt be: 2006-ig Dióssy László, az SZDSZ és MSZP színekben induló politikus vezette a várost, de 2006-ban kikapott a fideszes Debreczenyi Jánostól. Debreczenyi 2010-ben nem indult újra, helyét Porga Gyula vette át. Öt esetből szintén négyszer került megválasztásra az inkumbens városvezető.

Tatabányán Bencsik János vezette a várost 2010-ig. 1994-ben még SZDSZ színekben, utána két választáson keresztül függetlenként, majd 2006-ban a Fidesz támogatásával indult. 2010-ben nem indult, helyette a szintén Fidesz támogatottságú Schmidt Csaba vette át a várost. 2019-ben elveszítette a tisztségét az ellenzéki pártok által támogatott Szücsné Posztovics Ilonával szemben. Ennél a városnál is öt újraindulásból négyszer az inkumbens volt sikeres.

Székesfehérváron egy cikluson át, 1994-ben Nagy István került megválasztásra, majd 1998-tól az MSZP és SZDSZ támogatását is maga mögött tudó Warvasovszky Tihamér vezette a várost 2010-es visszavonulásáig. Nagy István 1998-ben megméretette magát, de nem került újra megválasztásra. 2010 után Cser-Palkovics András vezeti a várost a Fidesz párttámogatással. Öt újraindulás kísérletből szintén négy volt sikeres.

Szegeden 1994-ben Szalay István volt a nyertes MSZP-SZDSZ háttérrel. 1998ban legyőzte ellenfele, a jobboldali támogatottságú Bartha László, aki viszont 2002ben nem indult újra. Azóta a várost Botka László vezeti, 2019-ig az MSZP színeiben, 2019-ben pedig az Összefogás Szegedért Egyesület támogatásával. Az előzőeknek megfelelően öt próbálkozásból négyszer volt sikeres az inkumbens politikus.

Debrecenben 1994-ben az SZDSZ-es Hevessy József került ki győztesen, de a következő választáson elbukott a fideszes Kósa Lajossal szemben, aki 2014-ig volt a város polgármestere. Kósa Lajos szavazatszámai kiugróan magasak, minden esetben 50 \% fölötti volt. 2014-ben nem indult a polgármesteri székért, hogy megtarthassa országgyűlési képviselői helyét. Utódja a szintén Fidesz-KDNP-vel induló Papp László. Debrecenben is ötből négyszer nyerni tudott az inkumbens jelölt.

Nyíregyházán ötször szavazták vissza a polgármestert pozíciójában. 1994 és 2010 között a szocialista Csabai Lászlóné, majd az ő visszavonulása óta a fideszes 
Kovács Ferenc vezeti a várost 2010 után. Mivel 2010-ben Csabai Lászlóné nem indult, így ennél magasabb újraválasztási rátára lehetőség sem adódott.

Győrött hasonló szituáció alakult ki: 1994 és 2006 között a szocialista Balogh József irányította a települést, míg 2006 után a fideszes Borkai Zsolt. 2006-ban Balogh József nem indult újra. Érdemes kiemelni Borkai Zsolt 2019-es eredményét. Első győzelmén a szavazatok 49,53 \%-át szerezte, amit utána 2010-ben (69,67 \%) és 2014-ben (61,02 \%) jelentősen növelni tudott. A 2019-es helyhatósági választások előtt kirobbant botránya utána mindössze a szavazók 44,32 \%-át tudta maga mellé állítani, de így is ő lett a választás nyertese. Az eset jól tükrözi, hogy egy inkumbens politikus számára hátrányt is jelenthet pozíciója, hiszen a negatívan megítélt lépeseire sokkal nagyobb figyelem irányul, mint egy kihívó helyzetben lévő aspiránsra.

Kaposvár az újraválasztások száma és az inkumbens előny tekintetében is kiemelkedik. Szita Károly 1994 óta vezeti a várost, és 2019-ig hatszor választották újra. A Fidesz és aktuális választási évtől függően más jobboldali pártok által támogatott polgármester azóta folyamatosan a szavazatok több, mint felével tudott győzedelmeskedni. A rekord 1998-ban volt, amikor a kaposváriak 80,01 \%-a voksolt rá első újraindulásakor.

A példákból levonható a következtetés, hogy a magyarországi megyei jogú városokban az inkumbencia előny megjelenik, de erős befolyásolási tényező az azonos évben tartott országgyúlési választások eredménye, illetve a rendkívüli politikabefolyásoló események.

\section{Inkumbens indulók választásonként}

A huszonhárom megyei jogú városban választásonként változó számú az inkumbens indulók létszáma. Annak kifejezésére, hogy mennyire jelenik meg az inkumbencia előny ezeken a településeken, megvizsgálom, hogy az összes inkumbens induló közül hányan tudtak sikeresen szerepelni a választásokon. További szempontom, hogy a kormányzati pozícióban lévő pártok jelöltjei jobban teljesítenek-e az önkormányzati választásokon. Magyarországon 2014-ig minden önkormányzati és országgyülési voksolás azonos évben zajlott le. Mindig az országgyűlési választások estek az év első felére és a helyhatósági választások őszre. Ez lehetőséget ad az úgynevezett mézeshetek hatás kialakulásának. A mézeshetek hatás (honeymoon effect) lényege, egy első rendű (first order) választás után rövid idővel bekövetkező másodrangú (second order) választásokon az első rendű megmérettetés győztesei jobban szerepelnek (Karlheinz - Hermann 1980). A következőkben választásról választásra elemzem az alábbi táblázatok adatait. 
www. metszetek.unideb.hu

TEMATIKUS TANULMÁNYOK - Önkormányzati választások elméletben és gyakorlatban

3. táblázat. Inkumbens jelöltek újraválasztási aránya

\begin{tabular}{|c|c|c|c|c|}
\hline $\begin{array}{c}\text { Választás } \\
\text { éve }\end{array}$ & $\begin{array}{c}\text { Inkumbens } \\
\text { indulók száma }\end{array}$ & $\begin{array}{c}\text { Inkumbens } \\
\text { nyertesek száma }\end{array}$ & $\begin{array}{c}\text { Százalékos arányban } \\
\text { (összes induló) }\end{array}$ & $\begin{array}{c}\text { Százalékos arányban } \\
\text { (inkumbensek indulók) }\end{array}$ \\
\hline 1998 & 21 & 13 & $57 \%$ & $62 \%$ \\
\hline 2002 & 18 & 15 & $65 \%$ & $83 \%$ \\
\hline 2006 & 20 & 10 & $43 \%$ & $50 \%$ \\
\hline 2010 & 14 & 13 & $57 \%$ & $93 \%$ \\
\hline 2014 & 16 & 15 & $65 \%$ & $94 \%$ \\
\hline 2019 & 16 & 12 & $52 \%$ & $75 \%$ \\
\hline
\end{tabular}

Forrás: saját szerkesztés

4. táblázat. Inkumbens jelöltek újraválasztási aránya kormánypárti és nem kormánypárti megoszlásban

\begin{tabular}{|c|c|c|c|c|}
\hline $\begin{array}{c}\text { Választás } \\
\text { éve }\end{array}$ & $\begin{array}{c}\text { Kormánypárti } \\
\text { nyertes }\end{array}$ & $\begin{array}{c}\text { Kormánypárti } \\
\text { inkumbens nyertes }\end{array}$ & $\begin{array}{c}\text { Nem kormánypárti } \\
\text { nyertes }\end{array}$ & $\begin{array}{c}\text { Nem kormánypárti } \\
\text { inkumbens nyertes }\end{array}$ \\
\hline 1998 & 9 & 4 & 14 & 9 \\
\hline 2002 & 16 & 10 & 7 & 4 \\
\hline 2006 & 6 & 5 & 17 & 6 \\
\hline 2010 & 22 & 12 & 1 & 1 \\
\hline 2014 & 20 & 14 & 3 & 1 \\
\hline 2019 & 12 & 10 & 11 & 2 \\
\hline
\end{tabular}

Forrás: saját szerkesztés

A táblázatokból kiderül, hogy az inkumbens polgármesterek jelentős része indul a következő választásokon. 1998-ban indult újra a legtöbb polgármester, de csak 62\%-uk szerzett pozíciót. Másik fontos összefüggés, hogy hipotézisemmel ellentétesen a nem kormánypárti polgármesterek jobban szerepeltek a jobboldali kormánypárti jelölteknél (Fidesz, Független Kisgazda-, Földmunkás- és Polgári Párt és Magyar Demokrata Fórum).

2002-ben már sokkal sikeresebbek az inkumbens jelöltek, 83\%-uk tudta megtartani pozícióját. 2002-ben szintén kormányváltás következett be, az MSZP és SZDSZ vezetésével. E két párt több polgármestere is 1998-ban szerzett tisztséget, ami inkumbencia előnyt szerzett nekik. Ehhez hozzájárult még a mézeshetek hatás, ami a kormánypárti városvezetők dominanciájához vezetett.

2006 különleges év a magyar választástörténetben. Az általános választásokon nyert a kormányzó MSZP-SZDSZ koalíció, de az önkormányzati választások előtt kiszivárgott az Gyurcsány Ferenc miniszterelnök őszödi beszéd néven elhíresült 
hangfelvétele. Ennek hatására a választók „megbüntették” a kormánypártokat az önkormányzati választásokon. Bár húsz inkumbens polgármester indult el, de csak tíz tudta megtartani tisztségét. Látványos adat továbbá, hogy a kormánypárti oldalon mindössze hat polgármester tudott győzedelmeskedni és közülük öt inkumbens jelölt volt. A nem kormánypárti kihívók közül tizenegy új belépő volt, hiszen csak hat inkumbens induló az összesen tizenhét nem kormánypárti polgármester közül. A 2006-os eredmény szintén cáfolja azt a hipotézisemet, hogy a kormánypártok támogatottjai nagyobb arányban győzedelmeskednek. Azőszödi beszéd rendkívüli hatását viszont nem szabad alábecsülni.

A legkevesebb inkumbens induló 2010-ben volt, amikor a Fidesz-KDNP pártszövetség az általános választásokon kétharmados többséget szerzett az Országgyűlésben és a területi listákon megkapta a szavazatok 52,73\%-át. Az inkumbencia elmélet fontos része, hogy az inkumbens pozícióban lévő jelölt felismeri, amikor személye vagy pártállása már nem kedvez neki, s nagy valószínűséggel egy következő választáson elbukna. Ezért ilyen esetekben gyakran el sem indul, így kímélve meg magát a vereségtől. Erre hozza példának Kozma és Kumin Demszky Gábor esetét, aki 2010ben már nem indult Budapest főpolgármesteri címéért (Kozma - Kumin 2011). A 2010-es év rendhagyóságát bizonyítja továbbá, hogy csak egyetlen nem kormánypárti polgármester tudott győzni, Botka László személyében Szegeden. Rajta kívül sikertelenül próbálkozott még egy inkumbens nem kormánypárti polgármester: Szombathelyen Ipkovich György indult el, de nem tudott elérni egy újraválasztást.

2014-ben, szintén kétharmados többséget szerzett a Fidesz-KDNP az általános választásokon, s egy kivétellel az összes inkumbens jelöltjük győzelmet aratott. Az inkumbens jelöltek ezen a választáson teljesítettek a legjobban, köszönhetően a fenti körülményeknek. Fontos újdonság volt ebben az évben, hogy az országgyűlési képviselőség és a polgármesterség összeférhetetlen tisztségek lettek, így például az addig Debrecenben négy győzelmet elérő Kósa Lajos és a Hódmezővásárhelyen három győzelmet szerző Lázár János már nem indulhatott újra. Másik fontos újdonság, hogy ezután az önkormányzati ciklus öt évesre bővült.

A 2019-es választás az első öt éves ciklus utáni önkormányzati megmérettetés. Az eredmények az elmúlt két választáshoz képest már sokkal szorosabban alakultak, ami megmutatkozik a kormánypárti (tizenkét nyertes) és nem kormánypárti (tizenegy) polgármesterek számában. Továbbá az inkumbensek győzelmi aránya is csökkent (75\%), ami annak köszönthető, hogy négy kormánypárti városvezető sem tudott győzedelmeskedni. Négy esetben sikerült a nem kormánypárti kihívónak legyőznie a kormánypárti inkumbens jelöltet: Dunaújváros, Eger, Érd és Tatabánya. A tizenegy nem kormánypárti győzelemből kettő inkumbens jelölt volt: Szarvas Péter Békéscsabán és Botka László Szegeden. A négy említett városban a kihívó legyőzte az inkumbenst és öt másik esetben nem újrázott a kormánypárti polgármester. Ez mutatja, hogy amikor egy városban új verseny nyílik meg, a kihívó nagyobb eséllyel 
győzedelmeskedhet. A Fidesz-KDNP tizennégy inkumbenst indított és ebből négyet veszített el.

Az öt éves ciklus egy újabb politikatudományi jelenséget hoz be a képletbe: a kormányzati ciklus közepén tartott választásokon általában a kormánypárti jelöltek rosszabbul szerepelnek. Az Egyesült Államok kutatói szintén élen jártak ezen a területen (Tufte 1975). Megfigyelték, hogy az elnöki (kormányzati) ciklus közepén tartott úgynevezett (midterm) kongresszusi választásokon rosszabbul szerepelnek az elnök pártjához tartozó jelöltek. Ez a jelenség kiterjeszthető a magyar esetre is. Eddig az önkormányzati választások inkább a mézeshetek periódus idejéhez tartoztak, de a törvényhozási és az önkormányzati ciklusok eltolásával 2019-ben, amikor majd 1,5 év különbség volt a kettő között, közel a ciklus közepére tolódott a másodrendű választás. Ez negatívan befolyásolhatja a kormánypártok szereplését.

\section{Összegzés}

Jelen tanulmányban az inkumbencia és inkumbencia előny megjelenési formáit vizsgáltam a megyei jogú városokban. Megállapítható, hogy a megyei jogú városok közül tizenegyben magas az újraválasztások száma (négy vagy annál több újraválasztás). Nyolc városban átlagos, három újraválasztás tapasztalható. Az alacsony újraválasztási ráta inkább anomália. Ez az inkumbencia előny erős jelentőségét indikálja.

Az inkumbens polgármesterek magas arányban megpróbálnak újrázni és sikerességük legalacsonyabb foka mindössze 50\%-ra csökkent 2006-ban. Kiemelendőek azok az évek, amikor a kormányzati pozícióban lévő pártok nem tudták megszerezni a polgármesteri székek többségét a huszonhárom városban. 1998-ban a megyei jogú városokban nem múködött magas fokon a mézeshetek hatás, mert az önkormányzati választásokon a jobboldali kormánypárt polgármester-jelöltjei nem tudták megszerezni a huszonhárom település többségét. 2002 és 2010 viszont igazolja, hogy a kormánypártok törvényhozási választási sikerei kihathatnak a polgármester-választásra. 2006 hatalmas jobboldali fordulatot hozott, mely egészen 2019-ig kitartott. A kormánypártok sikerének visszaesésére magyarázat lehet az öt éves ciklus bevezetése, mivel így a kormányzati ciklus közepe felé tolódott a másodrendű polgármester-választás.

Az előző megállapításokat figyelembe véve kijelenthető, hogy a megyei jogú városokban is erősen jelen van az inkumbencia előny. További érdemes kutatási lehetőséget biztosít más településtípusok hasonló vizsgálata. Budapest és annak kerületei szintén érdemleges elemzési potenciállal rendelkeznek. 
TEMATIKUS TANULMÁNYOK - Önkormányzati választások elméletben és gyakorlatban

\section{Irodalom}

Erikson, R. S. (1971): The Advantage of Incumbency in Congressional Elections. Polity, Vol. 3, No. 3. 395-405.

Karlheinz, R. - Hermann, S. (1980): Nine Second Order National Elections: A Conceptual Framework for the Analysis of European Election Results. European Journal of Political Research, 1980/8., Elsevier Scientific Publishing Company, Amsterdam, 3-44.

Kozma V. - Kumin F. (2010): Inkumbensek a magyar polgármesterek választási küzdelmeiben. Enyedi Zs. - Szabó A. - Tardos R. (szerk.): Új képlet. Választások Magyarországon. Demokrácia Kutatások Magyar Központja Alapítvány, Budapest, 123-148.

Levitt S. D. (1997): Decomposing the Sources of Incumbency Advantage in the U.S. House. Legislative Studies Quarterly, Vol. 22, No. 1. 45-60.

Magyarország közigazgatási helynévkönyve 2019. január 1. (2019). Központi Statisztikai Hivatal, Budapest

Online adatbázis: www.valasztas.hu

Papp Zs. (2016): Inkumbens-hátrány (Helyi kötődés és a személynek szóló szavazat Magyarországon). Politikatudományi Szemle. XXV. évfolyam, 2016/2., 31-56.

Tufte E. R. (1975): Determinants of the Outcomes of Midterm Congressional Elections. The American Political Science Review. American Political Science Association, 812-826. 